\title{
Cave Pygmarrhopalites Vargovitsh, 2009 (Collembola, Symphypleona, Arrhopalitidae) in United States
}

\author{
DOUGLAS ZEPPELINI ${ }^{1,2,5}$; STEVEN J. TAYLOR ${ }^{3} \&$ MICHAEL E. SLAY ${ }^{4}$ \\ ${ }^{1}$ Universidade Estadual da Paraíba - Centro de Ciências Biológicas e Sociais Aplicadas, Campus V. Laboratório de Sistemática e \\ Conservação de Microartrópodes, Rua Monsenhor Walfredo Leal, 487, Tambia, 58020-540, João Pessoa, PB, Brazil. \\ E-mail: zeppelini@daad-alumni.de \\ ${ }^{2}$ Associação Guajiru - Ciência - Educação - Meio Ambiente, Federal Inscription number 051176990001.98,Scientific Board. \\ Cabedelo, PB, Brazil \\ ${ }^{3}$ Illinois Natural History Survey, 1816 South Oak Street, Champaign, IL 61820-6953, USA. E-mail: sjtaylor@illinois.edu \\ ${ }^{4}$ The Nature Conservancy, 601 North University Avenue, Little Rock, AR 72705, USA.E-mail: mslay@tnc.org \\ ${ }^{5}$ Corresponding author
}

\begin{abstract}
Six new species of Collembola of the family Arrhopalitidae are described from the United States (Pygmarrhopalites leonardwoodensis sp. nov., P. plethorasari sp. nov., P. youngsteadtii sp. nov., P. buffaloensis sp. nov., P. shoshoneiensis sp. nov., and $P$. ashcraftensis sp. nov.) from caves in Missouri (2 spp.), Arkansas (2 spp.), Nevada, and Indiana, respectively. These new taxa, which display varying degrees of troglomorphy, are compared with previously known species and bring the total described species in North America to 41.
\end{abstract}

Key words: cave Collembola, taxonomy, new species, descriptions

\section{Introduction}

This is the third in a series of papers dealing with the family Arrhopalitidae in U.S. caves (Christiansen \& Bellinger 1996, Zeppelini \& Christiansen 2003). The genera Arrhopalites Börner, 1906 and Pygmarrhopalites Vargovitsh, 2009 are cosmopolitan, with recent species described from Ukraine (Vargovitsh 2005, 2009), Spain (Baquero et al. 2005), Brazil (Zeppelini 2006), and Korea (Park \& Kang 2007). Of 35 species known from North America, many occur in caves. Christiansen (1966) described the species $P$. altus (Christiansen), P. bimus (Christiansen), P. clarus (Christiansen), P. dubius (Christiansen), and P. hirtus (Christiansen) from U.S. caves and reported cave records for A. caecus (Tullberg), P. benitus (Folsom), P. pygmaeus (Wankel), and $P$. whitesidei (Jacot). Christiansen \& Bellinger (1996) described the species P. caedus (Christiansen \& Bellinger), P. carolynae (Christiansen and Bellinger), P. commorus (Christiansen \& Bellinger), P. jay (Christiansen \& Bellinger), P. lacuna (Christiansen \& Bellinger), P. marshalli (Christiansen \& Bellinger), $P$. pavo (Christiansen \& Bellinger), P. sacer (Christiansen \& Bellinger), P. silvus (Christiansen \& Bellinger), and P. texensis (Christiansen \& Bellinger) from caves in Oklahoma, Virginia, and Texas. Two years later, Christiansen and Bellinger (1998) described P. ater (Christiansen \& Bellinger) and P. lewisi (Christiansen \& Bellinger) from caves in Indiana. The most recent descriptions added the species A. incertus Zeppelini \& Christiansen, P. arca (Zeppelini \& Christiansen), P. hubbardi (Zeppelini \& Christiansen), P. madonnensis (Zeppelini \& Christiansen), P. obtusus (Zeppelini \& Christiansen), P. sapo (Zeppelini \& Christiansen), and $P$. sextus (Zeppelini \& Christiansen) from caves in Colorado, Virginia, and Idaho (Zeppelini \& Christiansen 2003). The U.S. Arrhopalitidae fauna continues to expand with discoveries of new species. Herein, we describe six new cave species and report new collections for previously described species. All known species 
TABLE 1. Bretfeld's (1999) grouping and biogeographic distribution (Good 1974) of the North American species of Arrhopalites and Pygmarrhopalites.

\begin{tabular}{|c|c|c|c|}
\hline Species & State & Group & Distribution \\
\hline A. incertus & Colorado & caecus-group & 8 \\
\hline A. caecus & Widespread & caecus -group & $7 \mathrm{a}, 7 \mathrm{~b}, 8$ \\
\hline P. ashcraftensis sp.nov. & Indiana & principalis-group & $7 \mathrm{a}$ \\
\hline P. buffaloensis sp.nov. & Arkansas & pygmaeus-group s. str. & $7 \mathrm{~b}$ \\
\hline P. youngsteadtii sp.nov. & Arkansas & pygmaeus-group s. str. & $7 \mathrm{~b}$ \\
\hline P. leonardwoodensis sp. nov. & Missouri & pygmaeus-group s. str & $7 \mathrm{~b}$ \\
\hline P. plethorasari sp.nov. & Missouri & pygmaeus-group s. str. & $7 \mathrm{~b}$ \\
\hline P. shoshoneiensis sp.nov. & Nevada & furcatus-group & 8 \\
\hline P. altus & Kentucky & pygmaeus-group s. str. & $7 \mathrm{a}$ \\
\hline P. bimus & Indiana & pygmaeus-group s. str. & $7 \mathrm{a}$ \\
\hline P. ater & Indiana & pygmaeus-group s. str. & $7 \mathrm{a}$ \\
\hline P. lewisi & Indiana & pygmaeus-group s. str. & $7 \mathrm{a}$ \\
\hline P. madonnensis & Illinois & principalis-group & $7 \mathrm{~b}$ \\
\hline P. sapo & Illinois & principalis-group & $7 \mathrm{~b}$ \\
\hline P. carolynae & Virginia & principalis-group & $7 \mathrm{~b}$ \\
\hline P. marshalli & Virginia & principalis-group & $7 \mathrm{~b}$ \\
\hline P. caedus & Virginia & pygmaeus-group s. str. & $7 \mathrm{~b}$ \\
\hline P. commorus & Virginia & pygmaeus-group s. str. & $7 \mathrm{~b}$ \\
\hline P. lacuna & Virginia & pygmaeus-group s. str. & $7 \mathrm{~b}$ \\
\hline P. pavo & Virginia, West Virginia, Missouri & pygmaeus-group s. str. & $7 \mathrm{~b}$ \\
\hline P. sacer & Virginia & pygmaeus-group s. str. & $7 \mathrm{~b}$ \\
\hline P. silvus & Virginia & pygmaeus-group s. str. & $7 \mathrm{~b}$ \\
\hline P. texensis & Texas & pygmaeus-group s. str. & $7 \mathrm{~b}$ \\
\hline P. dubius & Iowa, Minnesota, Arkansas & pygmaeus-group s. str. & $7 \mathrm{~b}$ \\
\hline P. jay & Oklahoma & furcatus-group & $7 \mathrm{~b}$ \\
\hline P. obtusus & Virginia & furcatus-group & $7 \mathrm{~b}$ \\
\hline P. sextus & Virginia & furcatus-group & $7 \mathrm{~b}$ \\
\hline P. hubbardi & Colorado & principalis-group & 8 \\
\hline P. bellingeri & Colorado & principalis-group & 8 \\
\hline P. arca & Idaho & pygmaeus-group s. str. & 8 \\
\hline P. principalis & Widespread & principalis-group & $7 \mathrm{a}, 7 \mathrm{~b}, 8$ \\
\hline P. whitesidei & Widespread & principalis-group & $7 \mathrm{a}, 7 \mathrm{~b}, 8$ \\
\hline P. benitus & Widespread & principalis-group & $7 \mathrm{a}, 7 \mathrm{~b}, 8$ \\
\hline P. hirtus & Widespread & principalis-group & $7 \mathrm{a}, 7 \mathrm{~b}, 8$ \\
\hline P. pygmaeus & Widespread & pygmaeus-group s. str. & $7 \mathrm{a}, 7 \mathrm{~b}, 8$ \\
\hline P. clarus & Widespread & pygmaeus-group s. str. & $7 \mathrm{a}, 7 \mathrm{~b}, 8$ \\
\hline P. amarus & Widespread & pygmaeus-group s. str. & $7 \mathrm{a}, 7 \mathrm{~b}, 8$ \\
\hline P. diversus & Widespread & pygmaeus-group s. str. & $7 \mathrm{a}, 7 \mathrm{~b}, 8$ \\
\hline
\end{tabular}


of the pygmaeus-group s. l. of the family were placed in the genus Pygmarrhopalites Vargovitsh, 2009, even though the diagnostic feature for the new genus, presence of the FSa seta on the tibiotarso of the first and second pair of legs, were studied only in the new species described here.

\section{Taxonomy}

Six new species are described from caves in the states of Indiana (1), Arkansas (2), Missouri (2) and Nevada (1). The biogeographic distribution according to Good (1974) and the morphospecies grouping following Bretfeld (1999) are provided in Table 1 for the six new and all known species which occurs in United States (biogeographic areas 7a, 7b and 8). All body measurements and relevant ratios are given in Table 2. The system of Nayrolles (1991) is used for labeling the apical organ of the third antennal segment and that of Lawrence (1979) for the anal valve chaetotaxy. The chaetotaxy of the head and dens follows Christiansen (1966) and Christiansen and Bellinger (1998), and the analysis of the morphology is based on females only. For details concerning the abbreviations used herein, see Christiansen and Bellinger (1996, 1998).

Abbreviations. Ant. I-IV—antennal segments I-IV.

Material deposit. Holotypes and paratypes are deposited at Illinois Natural History Survey (INHS), Champaign, Illinois.

For each species, the Köppen-Geiger climate classification is given following Kottek et al. (2006), physiographic provinces follow Fenneman and Johnson (1946) and Gray (2000).

\section{Pygmarrhopalites leonardwoodensis sp. nov. \\ pygmaeus-group s. str; Fig. 1}

Description. Animals white in alcohol. Dorsal body setae short on anterior and posterior part of the great abdomen, the posterior setae much longer than the anterior (Fig. 1A), posterior setae 0.56 times length of third unguis (Table 2). Ant. IV of holotype as long as cephalic diagonal, with five subsegments, apex with capitate sense rod (Fig. 1B). Ant. III not swollen basally; sense organ (Fig. 1C) with 2 sense rods in separate sockets; seta Aai club-shaped, blunt; Api and Ape slender, acuminate; Ae, Ap and Ai normal, elongate setae. 1+1 eyes. Dorsal cephalic setae not spine-like, M5 absent (Fig. 1D). Metatrochanteral organ (seta D2) elongate (Fig. 1E). Seta FSa present on all tibiotarsi. All ungues with inner tooth, no tunica. All unguiculi with corner tooth, apical filament reaching unguis tip of first and second claw pairs (Fig. 1F). Corpus tenaculum with two setae (Fig. 1G). Dens with 7 dorsal E setae, E1 and E3 strongly spine-like, other E setae normal; L1-3 strongly spine-like, 4 ventral setae rows $(3,2,1,1)$ present (Fig. 1H), dental chaetotaxy in Table 3. Mucro narrow, gutter-like, with narrow tip, both edges serrate (Fig. 1I). Anal valve without cuticular spines (Fig. 1J); setae C1 swollen, C3-4 slightly lamellate, C5-6 lamellate, C6 branched at base in all specimens examined, D5 present, D7 absent, chaetotaxy in Table 4. Female subanal appendage unilaterally fringed in distal half (Fig. $1 \mathrm{~K})$.

Type material. Holotype (female) (number 2 in the slide): USA, MISSOURI, Pulaski Co., Folly Cave, 12-iv-04, S. Taylor, M. Slay leg. (INHS). Paratypes: female, in the same slide with holotype and 5 paratypes in alcohol: USA, MISSOURI, Pulaski Co., Folly Cave, 12-iv-04, S. Taylor, M. Slay leg. (INHS).

Etymology. Refers to the military installation, Fort Leonard Wood, where the species is known to occur.

Remarks. Pygmarrhopalites leonardwoodensis was found in a single cave in Fort Leonard Wood, a military installation at the physiographic province Salem Plateau of the Ozark Plateaus. The climate is Cfa, temperate/mesothermal, humid subtropical with uniform precipitation distribution.

This species resembles P. madonnensis from Illinois in the foot complexes, head and apical organ of the third antennal segment chaetotaxies, and fourth antennal segment subsegmentation. The strongly serrated lamellae on C4-6 of P. madonnensis, and the short posterior body setae, the female subanal appendages, the presence of E7 and the L3 strongly spine-like on dens in P. leonardwoodensis can differentiate the species from each other. 


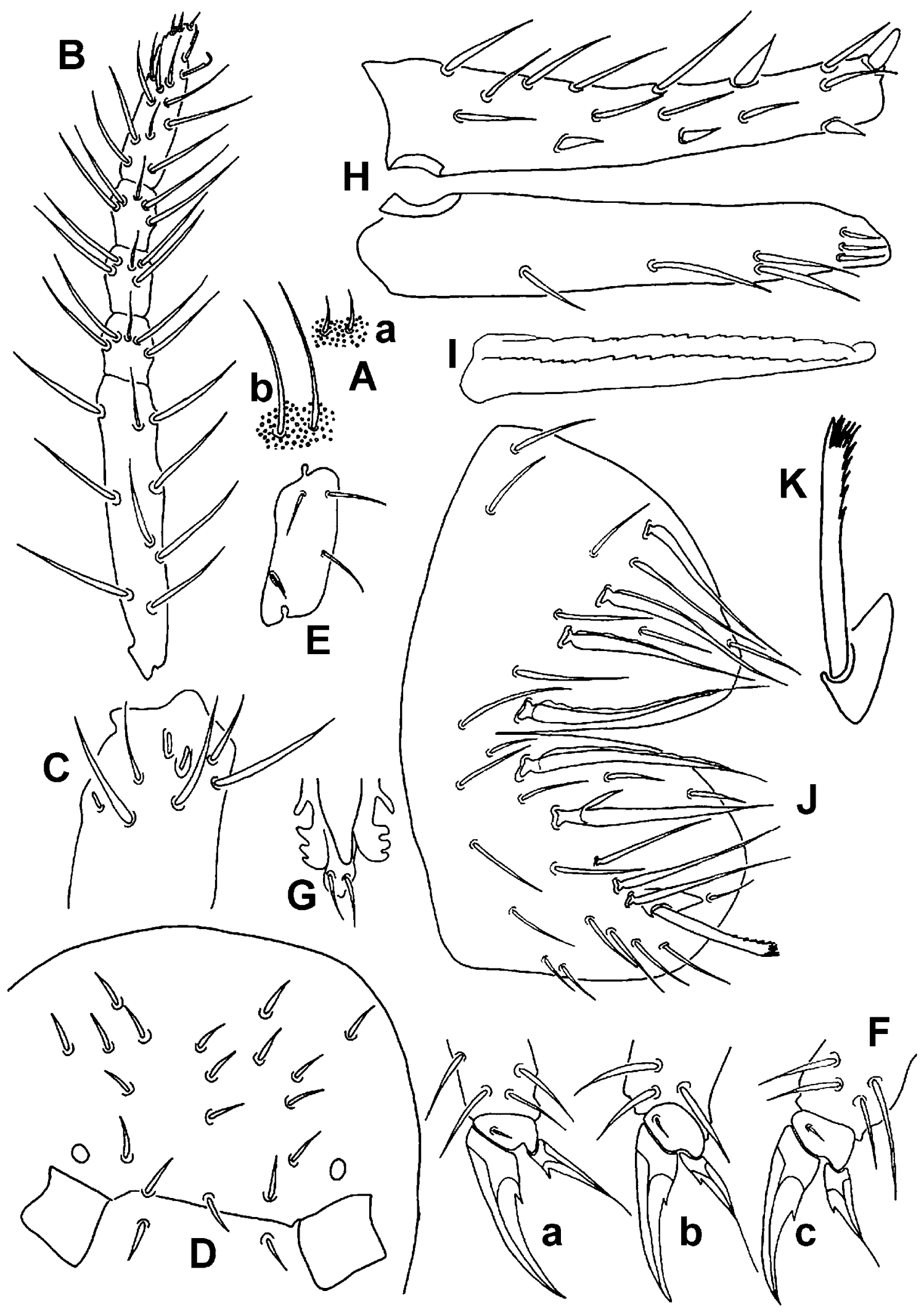

FIGURE 1. Pygmarrhopalites leonardwoodensis sp. nov.: A, Dorsal body seta (a- anterior part of the abdomen, bposterior part of the abdomen); B, Fourth antennal segment; C, Apical sensory organ of the third antennal segment; D, Posterior dorsal cephalic chaetotaxy; E, Metatrochanteral organ; F, Empodial complex (a — first leg, b-second leg, cthird leg); G, Tenaculum; H, Dorsal and ventral chaetotaxy of the dens; I, Mucro with narrow tip; J, Chaetotaxy of the anal valve; K, Subanal appendage of the female. 
TABLE 2. Measurements and ratios for structures of the holotypes of the six new species of Pygmarrhopalites. All measurements in micrometers.

\begin{tabular}{|c|c|c|c|c|c|c|}
\hline Structure or Ratio ${ }^{1}$ & $\begin{array}{l}P . \\
\text { ashcraftensis }\end{array}$ & $\begin{array}{l}P . \\
\text { leonardwoodensis }\end{array}$ & $\begin{array}{l}P . \\
\text { buffaloensis }\end{array}$ & $\begin{array}{l}P . \\
\text { youngsteadtii }\end{array}$ & $\begin{array}{l}P . \\
\text { plethorasari }\end{array}$ & $\begin{array}{l}P . \\
\text { shoshoneiensis }\end{array}$ \\
\hline \multicolumn{7}{|l|}{ Antennae and head } \\
\hline apic-antIV & 68.86 & 69.55 & - & 108.21 & 79.84 & 59.49 \\
\hline antIV sub seg 2 & 42.93 & 27.01 & - & 50.34 & 26.23 & 20.29 \\
\hline antIV sub seg 3 & 31.48 & 31.19 & - & 50.21 & 28.40 & 27.16 \\
\hline antIV sub seg 4 & 42.02 & 31.36 & - & 62.84 & 28.26 & 31.07 \\
\hline antIV sub seg 5 & 58.26 & - & - & 77.92 & - & 30.10 \\
\hline antIV sub seg 6 & - & - & - & 78.94 & - & 31.42 \\
\hline bas-antIV & 319.38 & 134.96 & - & 356.74 & 137.76 & 130.37 \\
\hline Total AntIV & 562.95 & 294.09 & - & 785.23 & 300.52 & 329.93 \\
\hline Longest Seta AntIV & 87.01 & 51.01 & - & 132.46 & 67.08 & 92.81 \\
\hline Widest Subseg AntIV & 24.06 & 19.80 & - & 32.46 & 17.83 & 21.13 \\
\hline ratio Lseta/Wsubseg & 3.61 & 2.57 & - & 4.08 & 3.76 & 4.39 \\
\hline Ratio AntIV/cep-diag & 1.80 & 1.00 & - & 1.56 & 1.32 & 1.34 \\
\hline cep-diag & 312.68 & 294.06 & - & 502.93 & 227.23 & 244.53 \\
\hline \multicolumn{7}{|l|}{ ratio Apical subseg/total } \\
\hline AntIV & 0.12 & 0.23 & - & 0.13 & 0.26 & 0.18 \\
\hline \multicolumn{7}{|l|}{ ratio Basal subseg/total } \\
\hline AntIV & 0.56 & 0.45 & - & 0.45 & 0.45 & 0.39 \\
\hline \multicolumn{7}{|l|}{ Body } \\
\hline post-bd-st & 99.51 & 29.31 & 102.49 & 119.52 & 58.44 & 86.61 \\
\hline ung-III & 74.39 & 52.11 & 83.24 & 111.81 & 56.56 & 62.81 \\
\hline Ratio post-bd-st/ung-III & 1.33 & 0.56 & 1.23 & 1.06 & 1.03 & 1.37 \\
\hline Total Body Length & 1071.67 & 1048.61 & 1052.47 & 1617.66 & 820.76 & 1244.59 \\
\hline \multicolumn{7}{|l|}{ Legs } \\
\hline Coxa 1 length & - & 57.45 & 57.35 & 114.34 & 43.49 & 62.94 \\
\hline Trochanter 1 length & 83.31 & 58.99 & 68.88 & 137.39 & 61.85 & 54.25 \\
\hline Femur 1 length & 188.73 & 113.98 & 137.66 & 269.29 & 115.83 & 110.37 \\
\hline Tibiotarsus 1 length & 332.19 & 168.29 & 281.11 & 475.49 & 239.45 & 210.1 \\
\hline Coxa 1 width & - & 30.88 & 41.12 & 84.11 & 29.78 & 47.07 \\
\hline Trochanter 1 width & 36.16 & 28.73 & 34.06 & 68.62 & 29.65 & 48.93 \\
\hline Femur 1 width & 34.99 & 43.27 & 55.55 & 67.89 & 35.14 & 36.39 \\
\hline Tibiotarsus 1 width & 33.74 & 25.63 & 33.64 & 57.86 & 26.11 & 32.73 \\
\hline Coxa 2 length & 62.45 & 45.85 & 55.04 & - & 58.81 & 56.98 \\
\hline Trochanter 2 length & 120.36 & 57.30 & 72.94 & - & 58.24 & 75.65 \\
\hline Femur 2 length & 189.19 & 120.1 & 165.55 & 340.4 & 136.33 & 134.6 \\
\hline Tibiotarsus 2 length & 372.86 & 231.69 & 290.21 & 505.95 & 247.66 & 240.38 \\
\hline Coxa 2 width & 55.48 & 36.01 & 53.44 & - & 26.75 & 55.65 \\
\hline Trochanter 2 width & 36.23 & 33.56 & 54.09 & - & 26.44 & 30.09 \\
\hline Femur 2 width & 34.19 & 41.48 & 53.84 & 87.47 & 41.21 & 42.07 \\
\hline Tibiotarsus 2 width & 29.78 & 24.17 & 38.47 & 38.35 & 25.68 & 25.57 \\
\hline
\end{tabular}


TABLE 2. (continued)

\begin{tabular}{|c|c|c|c|c|c|c|}
\hline Structure or Ratio ${ }^{1}$ & $\begin{array}{l}P . \\
\text { ashcraftensis }\end{array}$ & $\begin{array}{l}P . \\
\text { leonardwoodensis }\end{array}$ & $\begin{array}{l}P . \\
\text { buffaloensis }\end{array}$ & $\begin{array}{l}P . \\
\text { youngsteadtii }\end{array}$ & $\begin{array}{l}P . \\
\text { plethorasari }\end{array}$ & $\begin{array}{l}P . \\
\text { shoshoneiensis }\end{array}$ \\
\hline Coxa 3 length & - & 71.57 & 68.83 & 110.83 & 62.94 & 67.64 \\
\hline Trochanter 3 length & - & 72.85 & 103.49 & 159.59 & 85.11 & 86.31 \\
\hline Femur 3 length & 168.19 & 143.81 & 178.59 & 292.04 & 156.99 & 161.2 \\
\hline Tibiotarsus 3 length & 327.78 & 281.21 & 347.68 & 603.73 & 323.65 & 303.45 \\
\hline Coxa 3 width & - & 48.57 & 58.46 & 47.12 & 31.60 & 65.39 \\
\hline Trochanter 3 width & - & 31.83 & 43.62 & 65.41 & 33.71 & 35.19 \\
\hline Femur 3 width & 45.18 & 43.37 & 53.39 & 54.50 & 42.69 & 51.08 \\
\hline Tibiotarsus 3 width & 36.00 & 33.59 & 35.30 & 36.76 & 25.87 & 22.73 \\
\hline \multicolumn{7}{|l|}{ Length/Width Ratio } \\
\hline Coxa 1 & - & 1.86 & 1.39 & 1.35 & 1.46 & 1.33 \\
\hline Trochanter 1 & 2.30 & 2.05 & 2.02 & 2.00 & 2.08 & 1.10 \\
\hline Femur 1 & 5.39 & 2.63 & 2.47 & 3.96 & 3.29 & 3.03 \\
\hline Tibiotarsus 1 & 9.84 & 6.56 & 8.35 & 8.21 & 9.17 & 6.41 \\
\hline Coxa 2 & 1.12 & 1.27 & 1.03 & - & 2.19 & 1.02 \\
\hline Trochanter 2 & 3.32 & 1.70 & 1.34 & - & 2.20 & 2.51 \\
\hline Femur 2 & 5.53 & 2.89 & 3.07 & 3.89 & 3.30 & 3.19 \\
\hline Tibiotarsus 2 & 12.51 & 9.58 & 7.54 & 13.19 & 9.64 & 9.39 \\
\hline Coxa 3 & - & 1.47 & 1.17 & 2.35 & 1.99 & 1.03 \\
\hline Trochanter 3 & - & 2.28 & 2.37 & 2.43 & 2.52 & 2.45 \\
\hline Femur 3 & 3.72 & 3.31 & 3.34 & 5.35 & 3.67 & 3.15 \\
\hline Tibiotarsus 3 & 9.10 & 8.37 & 9.84 & 16.42 & 12.50 & 13.34 \\
\hline \multicolumn{7}{|l|}{ Dens } \\
\hline Dens Length & 328.2 & 188.11 & 286.72 & 467.72 & 219.96 & 202.62 \\
\hline Dens Width & 41.41 & 31.62 & 36.86 & 49.97 & 30.86 & 37.43 \\
\hline \multicolumn{7}{|l|}{ Length/Width Ratio- } \\
\hline Dens & 7.92 & 5.94 & 7.77 & 9.35 & 7.12 & 5.41 \\
\hline
\end{tabular}

${ }^{1}$ Abbreviations in parentheses are used in the table above: Antennae and head: Apical subsegment of the fourth antennal segment (apic-antIV), second subsegment of the fourth antennal segment (antIV sub seg 2), third subsegment (antIV sub seg 3), fourth subsegment (antIV sub seg 4), fifth subsegment (antIV sub seg 5), sixth subsegment (antIV sub seg 6), basal subsegment of the fourth antennal segment (bas-antIV), total length of the fourth antennal segment (Total AntIV), longest seta of the segment (Longest Seta AntIV), widest subsegment of the fourth antennal segment (Widest Subseg AntIV), ratio of the longest seta and the widest subsegment width (ratio Lseta/Wsubseg), ratio of antIV total length and cephalic diagonal (Ratio AntIV/cep-diag), cephalic diagonal (cep-diag), ratio of apical subsegment and total length of fourth antennal segment (ratio Apical subseg / total AntIV), ratio of basal subsegment and total length of fourth antennal segment (ratio Basal subseg /total AntIV); Body: length of the posterior body seta (post-bd-st), maximum length of the third unguis (ung-III), ratio of posterior body seta and the third unguis length (ratio post-bd-st/ung-III), Total Body Length; Legs: length and width of coxa, trochanter, femur and tibia of all legs, ratio of length and width for each leg segment; Dens: dens length, dens width, ratio of length and width of dens (Length/Width Ratio-Dens).

\section{Pygmarrhopalites plethorasari sp. nov. pygmaeus-group s. str. (Fig. 2)}

Description. No traces of pigment, dorsal body setae short on anterior, longer on posterior part of great abdomen, posterior setae about same length as third unguis (Table 2). Ant. IV of holotype 1.32 times cephalic diagonal, with five subsegments (Fig. 2A), apex with capitate sense rod. Ant. III not swollen basally; sense 


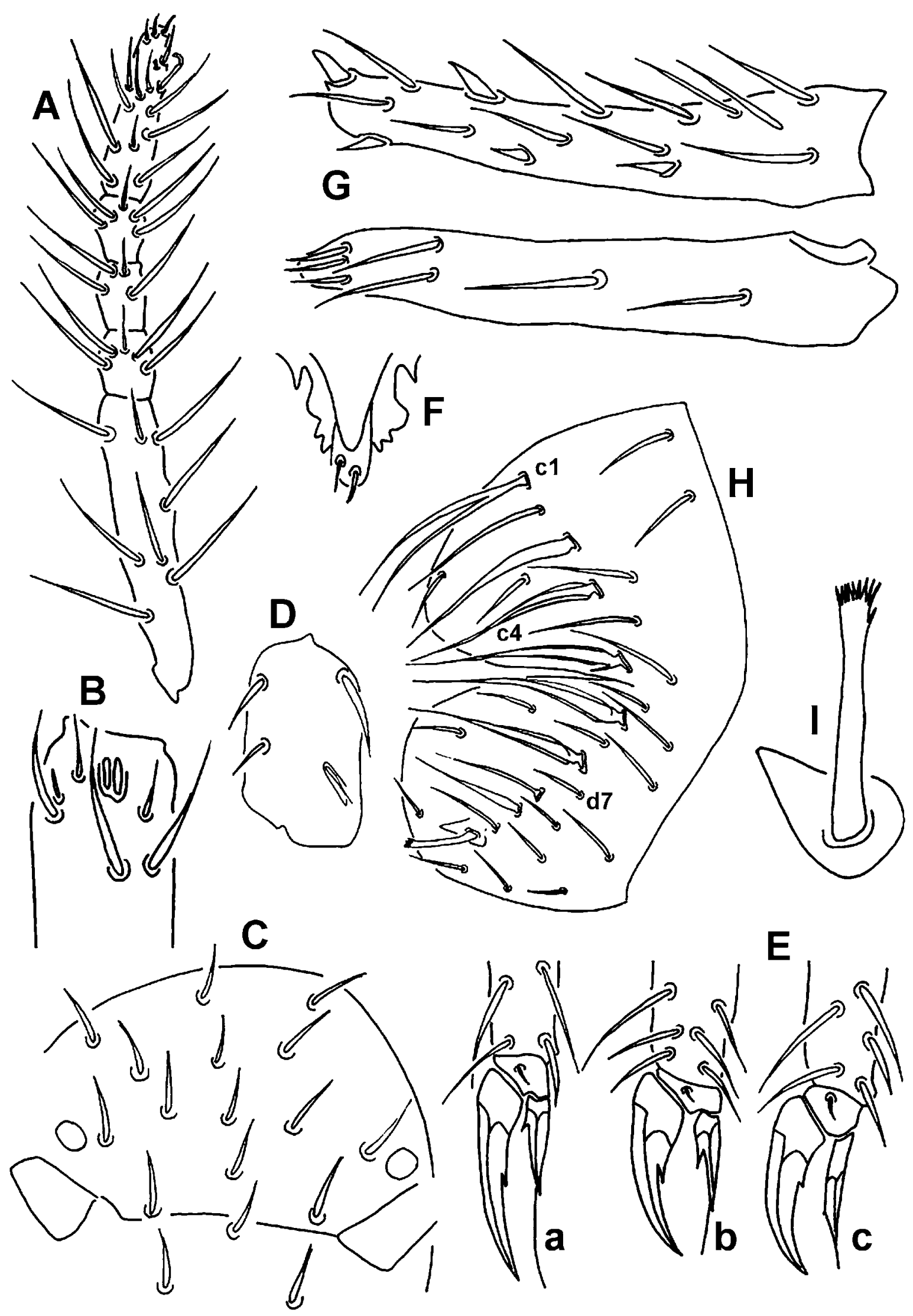

FIGURE 2. Pygmarrhopalites plethorasari sp. nov.: A, Fourth antennal segment; B, Apical sensory organ of the third antennal segment; C, Posterior dorsal cephalic chaetotaxy; D, Metatrochanteral organ; E, Empodial complex (a-first leg, b-second leg, c-third leg); F, Tenaculum; G, Dorsal and ventral chaetotaxy of the dens; H, Chaetotaxy of the anal valve; I, Subanal appendage of the female. 
organ (Fig. 2B) with 2 parallel sense rods in single socket; seta Aai club-shaped, acuminate; Api and Ape short, slender and acuminate; Ae, Ap and Ai normal, elongate setae. 1+1 eyes. Dorsal cephalic setae not spine-like, M5 present, L1-2 not seen (Fig. 2C). Metatrochanteral organ elongate (Fig. 2D). Seta FSa present on all tibiotarsi. All ungues with inner tooth, no tunica. First and second unguiculi with conspicuous corner tooth, third unguiculus slender, lanceolate, with tiny corner tooth in distal third, all unguiculi with apical filament exceeding unguis tip in first and second claw pairs (Fig. 2E). Corpus tenaculum with two setae (Fig. 2F). Dens with 7 dorsal E setae, E1 and E3 strongly spine-like, other E setae normal; L1-3 strongly spine-like, 4 ventral setae rows $(3,2,1,1)$ present (Fig. 2G), dental chaetotaxy in Table 3. Mucro narrow, gutter-like, with spoon shaped or globular tip, both edges serrate. Anal valve without cuticular spines (Fig. $2 \mathrm{H}$ ); setae $\mathrm{C} 1$ forked, C2 swollen, C3-4 slightly lamellate, C4 branched at base, C5-6 lamellate, D5 present, chaetotaxy in Table 4. Female subanal appendage fringed at tip (Fig. 2I).

TABLE 3. Cephalic and dental features of the six new species of Pygmarrhopalites.

\begin{tabular}{|c|c|c|c|c|c|c|c|c|c|c|c|c|c|c|c|c|}
\hline \multirow[b]{2}{*}{ Species } & \multirow[b]{2}{*}{$\begin{array}{l}\text { Ant. iv } \\
\text { subd. }\end{array}$} & \multirow[b]{2}{*}{$\begin{array}{l}\text { Ant. iii } \\
\text { basal }\end{array}$} & \multirow[b]{2}{*}{$\begin{array}{l}\text { Eyes per } \\
\text { side }\end{array}$} & \multirow[b]{2}{*}{$\begin{array}{l}\text { Ceph. } \\
\text { spines }\end{array}$} & \multicolumn{12}{|c|}{ Dental chaetotaxy } \\
\hline & & & & & $\mathrm{E} 1$ & $\mathrm{E} 2$ & E3 & E6 & E7 & $\begin{array}{l}\text { Id } \\
2-3\end{array}$ & $\mathrm{~L} 1$ & $\mathrm{~L} 2$ & L3 & $\mathrm{L} 4$ & $\begin{array}{l}\text { ve } \\
1\end{array}$ & $\begin{array}{l}\text { ve } \\
5\end{array}$ \\
\hline P. ashcraftensis & 6 & - & 1 & - & $\mathrm{S}$ & + & $\mathrm{S}$ & + & + & + & $\mathrm{S}$ & $\mathrm{S}$ & $\mathrm{s}$ & + & + & - \\
\hline P. leonardwoodensis & 5 & - & 1 & - & $\mathrm{S}$ & + & $\mathrm{S}$ & + & + & + & $\mathrm{S}$ & S & $\mathrm{S}$ & - & + & - \\
\hline P. buffaloensis & 6 & - & 1 & - & $\mathrm{S}$ & + & + & + & + & + & $\mathrm{S}$ & + & + & - & + & - \\
\hline P. youngsteadtii & 7 & - & 1 & - & $\mathrm{S}$ & + & S & + & + & + & $\mathrm{S}$ & $\mathrm{s}$ & - & - & + & - \\
\hline P. plethorasari & 5 & - & 1 & - & $\mathrm{S}$ & + & $S$ & + & + & + & $\mathrm{S}$ & $\mathrm{S}$ & $\mathrm{s}$ & - & + & - \\
\hline P. shoshoneiensis & 7 & - & $1 \mathrm{v}$ & - & $\mathrm{S}$ & + & + & + & + & + & $\mathrm{S}$ & $\mathrm{s}$ & $\mathrm{s}$ & - & + & - \\
\hline
\end{tabular}

$+=$ present, $-=$ absent, $S=$ strongly spine-like, $s=$ spine-like, $v=$ vestigial.

Type material. Holotype (female) (number 1 in the slide): USA, MISSOURI, Pulaski Co., Big Freeman Cave, 9-i-04, S. Taylor, M. Slay leg. (INHS). Paratypes: female in the same slide with holotype and 3 females: USA, MISSOURI, Pulaski Co., Ramsey Cave, 9-i-04, S. Taylor, M. Slay leg. (INHS). 8 paratypes in alcohol, same locality as the latter ones (INHS).

Etymology. An anagram of the name of the type genus of the family, Arrhopalites.

Remarks. Pygmarrhopalites plethorasari was found in caves of the Fort Leonard Wood military installation, close to each other in the physiographic province Salem Plateau of the Ozark Plateaus, the climate is Cfa. This species resembles $P$. hubbardi from Colorado in the apical filament of feet complexes, dental chaetotaxy, and the forked $\mathrm{C} 1$ seta on the anal valve. The fourth antennal subsegmentation and the basal swelling of the third antennal segment of $P$. hubbardi, the female subanal appendages, and the lamellate C setae on anal valve of $P$. plethorasari differentiate these species from each other.

\section{Pygmarrhopalites youngsteadtii sp. nov.}

pygmaeus-group s. str. (Fig. 3)

Description. Red pigment on and around eyes, one pair red spots on the posterior of head. Orange to red pigments scattered over anterior dorsal part of great abdomen. Dorsal body setae short on anterior part and about twice longer on posterior part of the great abdomen, posterior setae about same length as third unguis (Table 2). Ant. IV of holotype 1.56 times cephalic diagonal, with 7 subsegments (Fig. 3A), apex with capitate sense rod. Ant. III not swollen basally; sense organ (Fig. 3B) with 2 parallel sense rods in single, shallow pit; seta Aai slightly curved and blunt; Api and Ape slender, bristle-like, shorter than Ae; Ap and Ai normal, elongate setae. 1+1 minute eyes present. Dorsal cephalic setae not spine-like, M4-5 absent, L1-2 absent (Fig. 3C). Metatrochanteral organ elongate (Fig. 3D). Seta FSa present on all tibiotarsi. First unguis elongated 


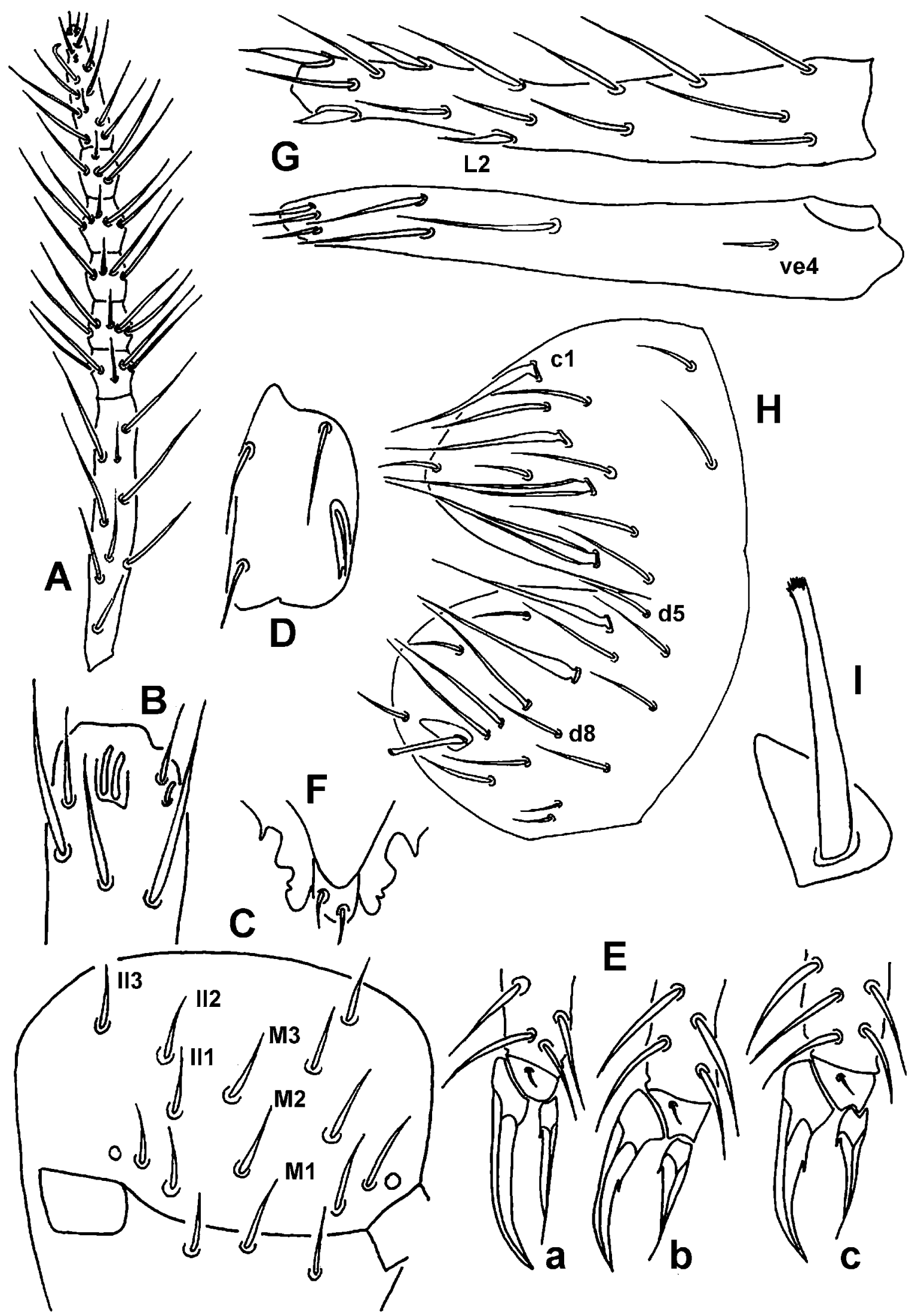

FIGURE 3. Pygmarrhopalites youngsteadtii sp. nov.: A, Fourth antennal segment; B, Apical sensory organ of the third antennal segment; C, Posterior dorsal cephalic chaetotaxy; D, Metatrochanteral organ; E, Empodial complex (a-first leg, b-second leg, c-third leg); F, Tenaculum; G, Dorsal and ventral chaetotaxy of the dens; H, Chaetotaxy of the anal valve; I, Subanal appendage of the female. 
without inner tooth, second and third with inner tooth, tunica absent. All unguiculi with conspicuous corner tooth, first unguiculus slender, all unguiculi with short apical filament, not exceeding unguis tip (Figs. 3E). Corpus tenaculum with two setae (Fig. 3F). Dens with 7 dorsal E setae, E1 and E3 strongly spine-like, other E setae normal; L1-2 spine-like, L3 absent, 4 ventral setae rows $(3,2,1,1)$ present, ve4 reduced (Fig. 3G), dental chaetotaxy in Table 3. Mucro narrow, gutter-like, with spoon shaped tip, both edges serrate. Anal valve without cuticular spines (Fig. 3H); setae C1, C2, C5 and C6 swollen basally, C3-4 lamellate, D5 present, D7 absent, chaetotaxy in Table 4. Female subanal appendage slightly flattened on distal third, fringed at tip (Fig. $3 \mathrm{I})$.

TABLE 4. Anal valve chaetotaxy of the six new species of Pygmarrhopalites.

\begin{tabular}{lcccccccccccccccc}
\hline Species & C1 & C2 & C3 & C4 & C5 & C6 & C7 & C8 & D5 & D7 & E8 & E9 & E10 & B10 & $\begin{array}{c}\text { Anal valve } \\
\text { spines }\end{array}$ \\
\hline P. ashcraftensis & + & + & + & + & + & + & + & + & + & - & + & - & + & D5 & - \\
P. leonardwoodensis & s & S & W & W & L & LB & + & S & + & - & + & + & + & C15 & - \\
P. buffaloensis & + & S & S & S & S & S & + & + & - & + & + & + & + & B5 & - \\
P. youngsteadtii & S & S & W & W & S & S & + & + & + & - & + & - & + & C10 & - \\
P. plethorasari & F & S & L & LB & L & L & + & S & + & + & + & + & + & BC10 & - \\
P. shoshoneiensis & F & + & S & S & S & S & + & + & - & - & + & - & + & E2 & - \\
\hline
\end{tabular}

$+=$ present in normal condition, $-=$ absent, $\mathrm{S}=$ swollen basally, $\mathrm{s}=$ slightly swollen basally, $\mathrm{L}=$ lamellate, $\mathrm{W}=$ weakly lamellate, F= forked, B= branched at the base. Subanal appendage coding follows Christiansen (1966).

Type material. Holotype (female): USA, ARKANSAS, Newton Co., Tom Barnes Cave, 18-ii-05, N. Youngsteadt, J. Youngsteadt leg. (INHS). Paratypes ( 2 adults females and 2 juveniles) in alcohol, same locality as holotype (INHS).

Etymology. The specific epithet recognizes the many years of work by Norman and Jean Youngsteadt contributing to a greater understanding of cave biota in the Ozarks.

Remarks. Pygmarrhopalites youngsteadtii type specimens were found in a single cave, at Buffalo National River in the same physiographic province as P. leonardwoodensis and P. plethorasari, is close to the former based on anal valve setae $\mathrm{C} 1$, which is bifid in A. plethorasari. They can be differentiated by features in Table 4. Despite of having a pair of eyes and pigments on the head and dorsum, this species presents some very typical cave features. The foot complex is highly troglomorphic, with very elongated unguis and short apical filaments, dens very slender (measurements in Table 2). This species is easily recognizable by a series of features. It presents a pair of pigment spots, like a false pair of eyes on the posterior part of the head, a fourth antennal segment 7 -subdivided, and a tiny ve4 seta on the ventral surface of dens, very displaced towards the base of the dens.

\section{Pygmarrhopalites buffaloensis sp. nov.}

pygmaeus-group s. str. (Fig. 4)

Description. No traces of pigment, dorsal body setae short, very scattered on anterior part, more than twice as long on posterior part of great abdomen, posterior setae longer than third unguis (Table 2). Ant. IV with 6 subsegments (Fig. 4A), apex with capitate sense rod. Ant. III not swollen basally; sense organ with 2 parallel sense rods in separate pits; seta Aai curved, blunt; Api and Ape slender, bristle-like and short, Ae, Ap and Ai normal elongate setae, more than twice as long as Ape and Api (Fig. 4B). 1+1 eyes present. Dorsal cephalic setae short, not spine-like, M4-5 present (Fig. 4C). Metatrochanteral organ elongate (Fig. 4D). Seta FSa present on all tibiotarsi. First unguis slender, elongated, all ungues with inner tooth, tunica absent. First 




FIGURE 4. Pygmarrhopalites buffaloensis sp. nov.: A, Fourth antennal segment; B, Apical sensory organ of the third antennal segment; C, Posterior dorsal cephalic chaetotaxy; D, Metatrochanteral organ; E, Empodial complex (a-first leg, b—second leg, c-third leg); F, Tenaculum; G, Dorsal and ventral chaetotaxy of the dens; H, Chaetotaxy of the anal valve; I, Subanal appendage of the female. 
unguiculus slender without corner tooth, apical filament exceeding unguis tip. Second and third unguiculi with short apical filament, third unguis lanceolate with corner tooth on distal third (Figs. 4E). Corpus tenaculum with two setae (Fig. 4F). Dens with 7 dorsal E setae, E1 strongly spine-like, other E setae normal; L1 spine-like, L2-3 present, 4 ventral setae rows $(3,2,1,1)$ present (Fig. 4G), dental chaetotaxy in Table 3. Mucro narrow, gutter-like, slightly spoon shaped tip, outer edge serrate, inner edge almost smooth. Anal valve without cuticular spines (Fig. 4H); setae C1 normal, C2-6 swollen basally, D5 absent, D6-10 present, chaetotaxy in Table 4. Female subanal appendage slightly palmate, deeply serrated distally (Fig. 4I).

Type material. Holotype (female) (number 1 in the slide): USA, ARKANSAS, Newton Co., Walnut Cave, 29-xii-2003, M.E. Slay, C.J. Bitting leg. (INHS). Paratypes: 1 female mounted in a slide and 2 adults in alcohol, same locality as holotype (INHS).

Etymology. The type specimens were collected from a cave near the Buffalo River, in northern Arkansas.

Remarks. Pygmarrhopalites buffaloensis was found in single cave at Buffalo National River approximately $26 \mathrm{~km}$ upstream from the cave containing $P$. youngsteadtii. The climate is Cfa, physiographic province Springfield Plateau of the Ozark Plateaus. This species resembles $P$. sapo by presenting the E2-7 not spine-like, and can be distinguished from this by the subanal appendages, the absence of D5 on anal valve, and most of its chaetotaxy.

\section{Pygmarrhopalites shoshoneiensis sp. nov. furcatus-group. (Fig. 5)}

Description. No traces of pigment, dorsal body setae short on anterior part and twice as long on posterior part of great abdomen, posterior setae longer than third unguis (Table 2). Ant. IV of holotype 1.34 times the cephalic diagonal, with 7 subsegments (Fig. 5A), apex with capitate sense rod. Ant. III not swollen basally; sense organ (Fig. 5B) with 2 parallel sense rods in separate pits; seta Aai straight, blunt; Api slender, bristlelike and short, Ape strong, short, acuminate, Ae, Ap and Ai elongate, about twice as long as Ape and Api. Eyes reduced to pair of smooth round spots in cuticle behind antennae. Dorsal cephalic setae slender, not spine-like, M4-5 present (Fig. 5C). Metatrochanteral organ elongate (Fig. 5D). Seta FSa present on all tibiotarsi. First unguis elongate, all ungues with inner tooth, tunica absent. First unguiculus slender, corner tooth very small or absent. Apical filament exceeding unguis tip in first and second unguiculi. Third unguiculus elongated, with corner tooth and short apical filament (Figs. 5E). Corpus tenaculum with two setae (Fig. 5F). Dens with 7 dorsal E setae, E1 strongly spine-like, other E setae normal; L1 strongly spine-like, L23 spine-like, 4 ventral setae rows $(3,2,1,1)$ present (Fig. 5G), dental chaetotaxy in Table 3. Mucro narrow, gutter-like, with narrow tip, outer edge serrate, inner edge smooth. Anal valve without cuticular spines (Fig. 5H); setae C1 forked, C3-6 swollen basally, D5 and D7 absent, chaetotaxy in Table 4. Female subanal appendage forked with both branches deeply fringed (Fig. 5I).

Type material. Holotype (female) (number 3 in the slide): USA, NEVADA, White Pine Co., Model Cave, 24-v-06, S.J. Taylor. J.K. Krejca, M.E. Slay leg. (INHS). Paratypes: 2 females (number 1 and 2) in the same slide with the holotype, and 6 adults in alcohol, same locality as holotype (INHS).

Etymology. The specific epithet refers to the Western Shoshone, a group of Native Americans who have visited the caves of Great Basin National Park for many hundreds of years, leaving behind only traces of their lives. Their tribal homeland encompasses large portions of the Basin and Range province of the Great Basin region.

Remarks. Pygmarrhopalites shoshoneiensis type specimens were found in a cave at Great Basin National Park. The physiographic province Basin and Range Province of the Great Basin, climate is BSk, dry, Steppe, middle latitude. This species resembles $P$. sextus in many aspects, including the shape of female subanal appendages and anal valve chaetotaxy, antenna/cephalic diagonal ratio, fourth antennal segment subdivision, and foot complex. The most important features that split them apart are the presence, in P. shoshoneiensis, of a forked $\mathrm{C} 1$ on the anal valve, the spine-like L1-3 on dens, the mucro with one smooth edge, the stout short Ape on apical organ of ant. iii, the presence of M5 on head, and the absence of a conspicuous eye. 




FIGURE 5. Pygmarrhopalites shoshoneiensis sp. nov.: A, Fourth antennal segment; B, Apical sensory organ of the third antennal segment; C, Posterior dorsal cephalic chaetotaxy; D, Metatrochanteral organ; E, Empodial complex (a-first leg, b-second leg, c-third leg); F, Tenaculum; G, Dorsal and ventral chaetotaxy of the dens; H, Chaetotaxy of the anal valve; I, Subanal appendage of the female. 
Pygmarrhopalites ashcraftensis sp. nov.

principalis-group. (Fig. 6)

Description. No traces of pigment, dorsal body setae short on anterior part, setae on posterior part of the great abdomen longer than third unguis (Table 2). Ant.IV of holotype 1.8 times cephalic diagonal, with 6 subsegments (Fig. 6A), apex with a capitate sense rod. Ant. III not swollen basally; sense organ (Fig. 6B) with 2 parallel sense rods in a single pit; seta Aai straight and blunt; Api slender and bristle-like, Ape short and bristle-like, Ae, Ap and Ai elongate, about twice as long as Ape. Eyes 1+1. Dorsal cephalic setae slender, not spine-like, M4 -5 present (Fig. 6C). Metatrochanteral organ elongate (Fig. 6D). Seta FSa present on all tibiotarsi. All ungues very slender, with a tiny inner tooth, tunica absent. First and second unguiculi slender, with clear corner tooth. Third unguiculus lanceolate, with corner tooth. All unguiculi with short apical filament, not exceeding the ungues tips (Fig. 6E). Corpus tenaculum with two setae (Fig. 6F). Dens with 7 dorsal E setae, E1 and E3 strongly spine-like; L4 present, L1 strongly spine-like, L2-4 spine-like, 4 ventral setae rows $(3,2,1,1)$ present (Fig. 6G), dental chaetotaxy in Table 3. Mucro narrow, with spoon shaped tip, gutter-like, both edges serrate (Fig. 6J). Anal valve without cuticular spines (Fig. 6H); all series of setae C normal, D5 present and D7 absent, chaetotaxy in Table 4. Female subanal appendage palmate, deeply serrated (Fig. 6I).

Type material. Holotype (female) (number 2 in the slide): USA, INDIANA, Greene Co., Ashcraft Cave, 20-viii-06, J. Lewis, S. Lewis leg. (INHS). Paratypes: 2 females marked with number 1 and 3 mounted in the same slide with the holotype, and 6 adults in alcohol, same locality as holotype (INHS).

Etymology: This species is named for the cave from which the types were collected. Ashcraft Cave, in the northern part of the Crawford Upland of Indiana, is at least 1851 meters (1.5 miles) in length and serves as a hibernaculum for the Indiana Bat, Myotis sodalis Miller and Allen.

Remarks. Pygmarrhopalites ashcraftensis was found on riparian mud banks in a cave. The physiographic province Crawford Upland of the Interior Lowland Plateaus, climate is Cfa. This species resembles $P$. lacuna and $P$. marshalli in different aspects, including the shape of female subanal appendages, fourth antennal segment subdivision, and foot complex. These species can be differentiated by the number of eyes, pigments, dental chaetotaxy, and anal valve chaetotaxy.

\section{Arrhopalites caecus (Tullberg, 1871)}

Material examined. USA: CALIFORNIA: Siskiyou Co.: Coral Reef Cave, 12-vi-05, S.J. Taylor, J.K. Krejca, J. Jacoby; NEVADA: White Pine Co.: Snake Creek Cave, 12-v-06, S.J. Taylor, J.K. Krejca, M.E. Slay, G. Baker; Lehman Cave, 26-v-06, J.K. Krejca, M.E. Slay, G. Baker, B. Roberts, M. Horner.

Remarks. This is the first record for California and Nevada, the species A. caecus has a world wide distribution.

\section{Pygmarrhopalites dubius (Christiansen, 1966)}

Material examined: USA: ARKANSAS: Marion Co.: Forest Trail Ridge Cave, 5-vi-04, M.E. Slay, E. Frank, J. Terry.

Remarks. This species was described from caves in Iowa and Minnesota (Christiansen 1966), so the occurrence in Arkansas is intriguing. Although P. dubius may only be a geographic variant of $P$. pygmaeus (Christiansen 1966, Christiansen \& Bellinger 1998), there is sufficient morphological differentiation to designate them as a separate species. Additionally, they were collected from the same cave, Forest Trail Ridge Cave, which provides support for a separate status of the species. 


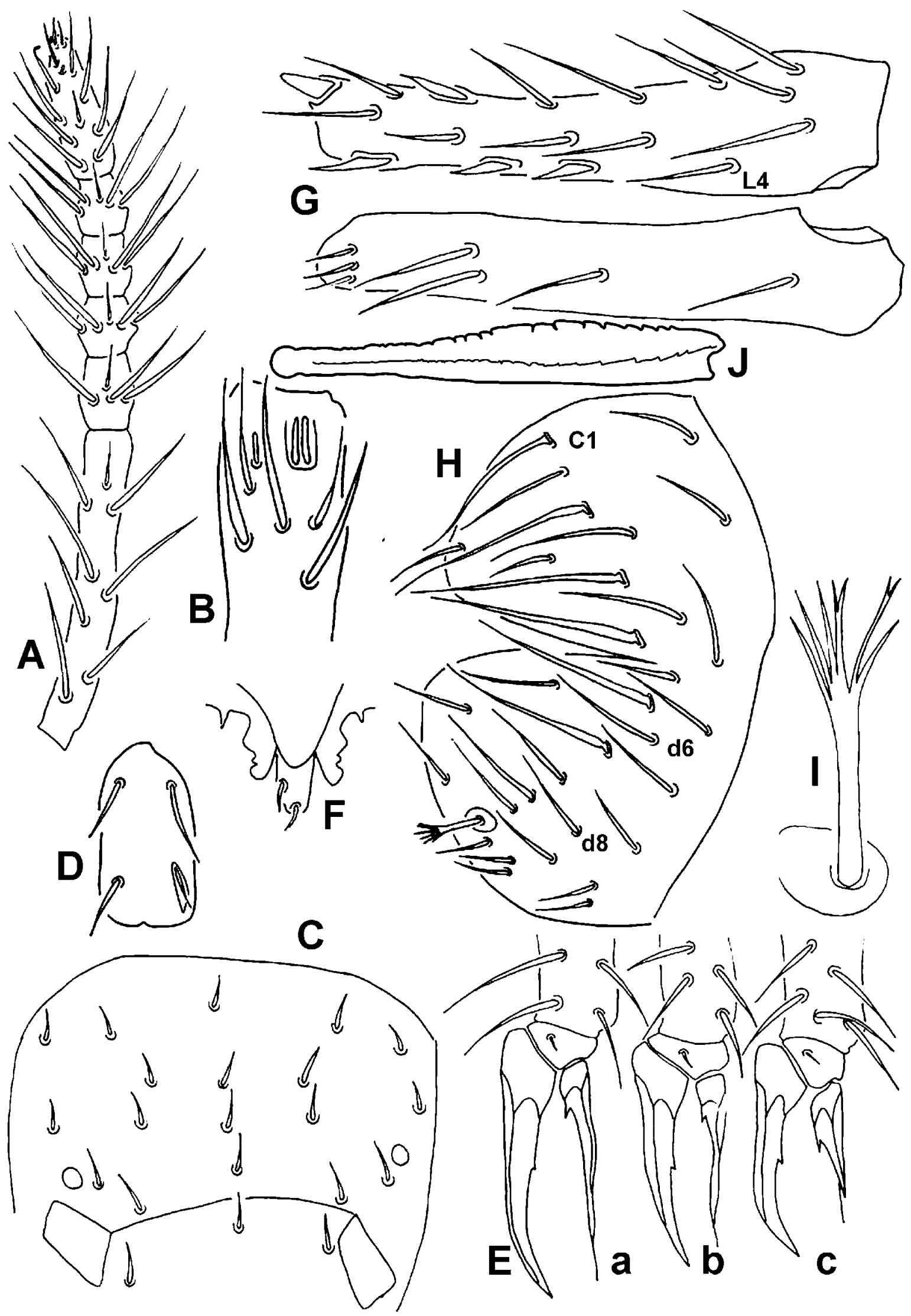

FIGURE 6. Pygmarrhopalites ashcraftensis sp. nov.: A, Fourth antennal segment; B, Apical sensory organ of the third antennal segment; C, Posterior dorsal cephalic chaetotaxy; D, Metatrochanteral organ; E, Empodial complex (a-first leg, b-second leg, c-third leg); F, Tenaculum; G, Dorsal and ventral chaetotaxy of the dens; H, Chaetotaxy of the anal valve; I, Subanal appendage of the female; J, mucro with spoon-shaped tip. 
Material examined. USA: WISCONSIN: Pierce Co.: Crystal Cave, 27-viii-06, J. Lovaas.

Remarks: This is the first record of $P$. hirtus in Wisconsin, the species is widespread in US.

\section{Pygmarrhopalites lewisi (Christiansen \& Bellinger, 1998)}

Material examined. USA: INDIANA: Crawford Co.: Robinson Ladder Cave, no date, J. Lewis, S. Lewis.

Remarks. Previously known from two caves in Crawford County and a cave in Washington County (Christiansen \& Bellinger 1998).

\section{Pygmarrhopalites pavo (Christiansen \& Bellinger, 1996)}

Material examined. USA: MISSOURI: Pulaski Co.: Henshaw Cave, 18-iv-06, S.J. Taylor, V.R. Block.

Remarks. This troglobiont was previously known only from a few caves in Virginia and West Virginia (Christiansen \& Bellinger 1996, Fong et al. 2007). Its confirmed presence in Missouri suggests a wider distribution than previous collections indicate.

\section{Pygmarrhopalites pygmaeus (Wankel, 1860)}

Material examined: USA: ARKANSAS: Marion Co.: Forest Trail Ridge Cave, 8-vi-04, M.E. Slay, C.J. Bitting; Long Ear Mine, 28-v-04, M.E. Slay, W. Baker; Morning Star Mine \#5, \#6, 29-v-04, M.E. Slay, C.J. Bitting; Morning Star Mine \#7, 7-vi-04, M.E. Slay; Overlook(ed) Cave, 8-vi-04, M.E. Slay, C.J. Bitting; Square Cave, 25-vii-04, Tony Bend Mine \#3, 26-vii-04, M.E. Slay, C. Brickey; Newton Co.: Hutchinson Waterfall Cave, 29-xii-04, M.E. Slay, C.J. Bitting, C.A. Melhart; NW41bb Cave, 4-iii-06, W. Baker; Toney Barnes Cave, 16-ix-04, M.E. Slay, C.J. Bitting; Seashell Dome Cave, 11-xii-05, M.E. Slay, C. Brickey; MISSOURI: Pulaski Co.: Andy's Cave \#1, \#2, 11-iv-04, S.J. Taylor, M.E. Slay, J. Jacoby; Breeden Cave, $25-$ x-03, S.J. Taylor, M.E. Slay; Brooks Cave, 18-vi-04, M.E. Slay; Chuck's Virgin Cave, 20-Apr-03, S.J. Taylor, M.E. Slay; David's Cave, 28-iii-03, Davis Cave \#1, 27-iii-03, S.J. Taylor, V.R. Block; Davis No. 2 Cave, 17vi-04, Davis No. 3 Cave, 26-x-03, S.J. Taylor, M.E. Slay; Deadman Cave, 19-iv-03, S.J. Taylor, V.R. Block; Eight Cave, 24-x-03, Joint East Cave, 10-iv-04, Joint West Cave, 10-iv-04, S.J. Taylor, M.E. Slay; Joy Cave, 18-vi-04, M.E. Slay; Kerr Cave, 26-iii-03, K. Lohraff, S.J. Taylor, V.R. Block; Kilman Cave, 25-iii-03, King Cave, 28-iii-03, Lohraff Cave, 28-iii-03, S.J. Taylor, V.R. Block; Lower Hooten Cave, 14-v-04, S.J. Taylor, M.E. Slay; Martin Cave, 29-v-03, S.J. Taylor, V.R. Block; Martin Cave, 14-v-04, S.J. Taylor, M.E. Slay, K. Lohraff; Miller Cave, 22-iii-03, M.E. Slay, S.J. Taylor, V.R. Block; New Arch Cave, 5-ix-04, M.E. Slay, C.A. Melhart, S.J. Taylor; Paleospring Cave, 21-xii-04, Saltpeter Cave, 9-i-04, S.J. Taylor, M.E. Slay; Turtle Trap Cave, 6-ix-04, M.E. Slay, C.A. Melhart; Wilson Cave, 8-i-04, S.J. Taylor, M.E. Slay; Wolf Den Cave, 15-vi04, S.J. Taylor, M.E. Slay, K. Lohraff; OKLAHOMA: Adair Co.: Pea Vine Cave, 2-v-04, G.O. Graening, D.B. Fenolio, M.E. Slay; Delaware Co.: Rock Quarry Cave, 25-vii-05, Surprise Cave, 27-vii-05, G.O. Graening, M.E. Slay.

Remarks. Nearly all collections were taken within dark zones with the exception of six samples from twilight zones and one sample collected from an entrance. For a subset of records $(n=34)$, relative humidity and temperature were recorded (mean $\pm \mathrm{SE}$ ). Average relative humidity was $94.34 \pm 0.67 \%$, average temperature at $2 \mathrm{~cm}$ soil depth was $13.6 \pm 0.35^{\circ} \mathrm{C}$, and average temperature $1 \mathrm{~m}$ above cave floor was $14.93 \pm$ $0.49^{\circ} \mathrm{C}$. Of 40 collections where sampling method was noted, $33(82.5 \%)$ were from pitfall traps baited with 
limburger cheese (traps were in place for 3-6 days). The remaining 7 (17.5\%) P. pygmaeus samples were collected by hand.

\section{Discussion}

The present work brings the number of species of the family Arrhopalitidae in North America up to 41, two species of the genus Arrhopalites and 39 species of Pygmarrhopalites, but the fauna is still poorly known (see discussion, Zeppelini \& Christiansen 2003). Previously, a single troglobite, P. clarus, was reported from Arkansas and Missouri (Christiansen 1982). Yet, recent inventories by the junior authors in Missouri and Arkansas yielded four new species and records for $P$. pavo and $P$. dubius increasing the number of cave Pygmarrhopalites in these states to seven. Such an increase in richness highlights explanations of regional differences given by Zeppelini and Christiansen (2003), namely collecting biases and the difficulty of collecting specimens .

Baited pitfall traps proved a successful technique to collect Arrhopalitidae in this study, although a direct comparison of techniques was not evaluated. The species P. leonardwoodensis, P. pavo, P. plethorasari were collected using pitfall traps baited with limburger cheese, while the species $P$. buffaloensis, $P$. dubius, and $P$. youngsteadtii were only collected by hand. No effort was made to use baited pitfall traps at caves containing $P$. buffaloensis and $P$. youngsteadtii, therefore it is unknown whether these two species could be captured by trapping. The species $P$. pygmaeus was captured using both techniques.

\section{Acknowledgements}

We thank the individuals listed in the collection records for their assistance during fieldwork; without their help, this project would not have been accomplished. Funding for this study was provided by multiple sources: Arkansas Game \& Fish Commission, Fort Leonard Wood Military Installation, Illinois Natural History Survey, The Nature Conservancy (Arkansas Field Office), University of Arkansas, University of Illinois, US National Park Service (Buffalo National River, Great Basin National Park, Lava Beds National Monument). We are grateful to Felipe Soto-Adames (Illinois Natural History Survey) for checking the chaetotaxy of the tibiotarsus. J.M. Betsch and anonymous referee provided important commentaries which helped to improve the manuscript.

\section{References}

Baquero, E., Herrando-Perez, S. \& Jordana, R.. (2005) A new species of Arrhopalites (Collembola, Symphypleona, Arrhopalitidae) from a cave on the Central East Iberian Peninsula. Subterranean Biology, 3, 81-86.

Börner, C. (1906) Das System der Collembolen nebst Beschreibung neuer Collembolen des Hamburger Naturhistorischen Museums. Mitteilungen aus den Naturhistorischen Museum in Hamburg, 23, 147-188.

Bretfeld, G. (1999) Symphypleona. In: Dunger W. (Ed.) Synopses on Palaearctic Collembola, vol. 2. Abhandlungen und Berichte des Naturkundemuseum Görlitz, 71, 1-318.

Christiansen, K. (1966) The genus Arrhopalites (Collembola: Sminthuridae) in the United States and Canada. International Journal of Speleology, 2, 43-73.

Christiansen, K. (1982) Zoogeography of cave collembolan east of the Great Plains. NSS Bulletin, 44, 32-41.

Christiansen, K. \& Bellinger, P. (1996) Cave Arrhopalites: new to science. Journal of Cave and Karst Studies, 58, 168180.

Christiansen, K. \& Bellinger, P. (1998) The Collembola of North America, north of the Rio Grande. A taxonomic analysis. Grinnell College, Grinnell, Iowa, $1520 \mathrm{pp}$.

Fong, D.W., Culver, D.C., Hobbs, H.H. III \& Pipan, T. (2007) The invertebrate cave fauna of West Virginia, 2nd ed. West Virginia Speleological Survey Bulletin 16. 167 pp. 
Fenneman, N.M. \& Johnson, D.W. (1946) Physiographic divisions of the conterminous U. S. [map] U.S. Geological Survey, Washington, DC.

Good, R. (1974) The geography of flowering plants. Longman Group, United Kingdom (4 ${ }^{\text {th }}$ edition). 574 pp.

Gray, H.H. (2000) Physiographic Divisions of Indiana, IGS Special Report 61, Plate 1. Digital compilation by Sowder, K.H. Available fromhttp://igs.indiana.edu/geology/maps/statephysiography/physiography.cfm (accessed 15 February 2009)

Kottek, M., Grieser, J., Beck, C., Rudolf, B. \& Rubel, F. (2006) World map of the Köppen-Geiger climate classification updated. Meteorologische Zeitschrift, 15, 259-263.

Lawrence, P.N. (1979) The terminology of terminalia and cartography of chaetotaxy in the Collembola, its evolutionary significance and systematic utility. First International Seminar Apterygota, Siena, 69-80.

Nayrolles, P. (1991) La chétotaxie antennaire des collemboles symphyplèones. Travaux du Laboratoire d'Ecobioogique des Arthropodes Édaphiques Toulouse, 6, 1-94.

Park, K. \& Kang, J. (2007) Three new species of Arrhopalites (Collembola, Symphypleona, Arrhopalitidae) from Korea. Entomological Research, 37, 157-162.

Tullberg, T. (1871) Förteckning öfver svenska Podurider. Öfversigt af Kongliga Vetenskaps-Akademiens Förhandlingar, 28, 143-155.

Vargovitsh, R.S. (2005) Arrhopalites kristiani sp. n. (Collembola, Symphypleona, Arrhopalitidae) from a cave in eastern Carpathians. Vestnik Zoologii, 39, 67-73.

Vargovitsh, R.S. (2009) New cave Arrhopalitidae (Collembola: Symphypleona) from the Crimea (Ukraine). Zootaxa, 2047:1-47.

Wankel, H. (1860) Beiträge zur fauna des Mährischen Höhlen. Lotos, 10, 201-206.

Zeppelini, D. (2006) The genus Arrhopalites Börner, 1906 (Collembola, Appendiciphora, Arrhopalitidae) in the Neotropical Region, with description of four new cave species from Brazil. Zootaxa, 1124, 1-40.

Zeppelini, D. \& Christiansen, K. (2003) Arrhopalites (Collembola: Arrhopalitidae) in U.S. caves with the description of seven new species. Journal of Cave and Karst Studies, 65, 36-42. 